\title{
Provenance by site interaction and stability analysis of European beech (Fagus sylvatica L.) provenances grown in common garden experiments
}

\author{
By S. Stojnić( ${ }^{1) *}$, S. Orlović(1), D. Ballian ${ }^{2)}$, M. Ivanković ${ }^{3)}$,

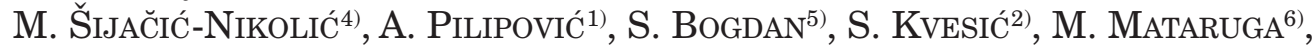

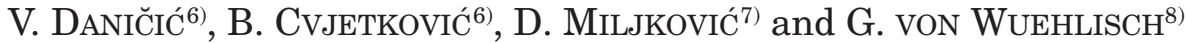

(Received $24^{\text {th }}$ February 2015)

\begin{abstract}
Fifteen provenances of European beech (Fagus sylvatica L.) were evaluated for stability and adaptability by height growth at four test sites in Bosnia and Herzegovina (1), Croatia (1) and Serbia (2). Provenance trials were established in spring 2007 by planting 2- and 3-yearold seedlings and arranged in a randomized complete block design. The data from seven 6year-old and eight 5-year-old provenances were obtained in 2009 and analyzed separately. Finlay and Wilkinson's regression analysis and Additive main effects and multiplicative interaction model (AMMI model) were used to assess provenance by site interaction $(\mathrm{P} \times \mathrm{S})$ and to identify beech provenances that have high and stable performance in different environments, at the juvenile stage of development. Analysis of
\end{abstract}

1) University of Novi Sad, Institute of Lowland Forestry and Environment, Antona Čehova 13, 21000 Novi Sad, Republic of Serbia.

2) University of Sarajevo, Faculty of Forestry, Zagrebačka 20, 78000 Sarajevo, Bosnia and Herzegovina.

$\left.{ }^{3}\right)$ Forest Research Institute, Cvjetno naselje 41, 10450 Jastrebarsko, Croatia.

4) University of Belgrade, Faculty of Forestry, Kneza Višeslava 1, 11000 Belgrade, Republic of Serbia.

5) University of Zagreb, Faculty of Forestry, Svetošumska cesta 25, 10000 Zagreb, Croatia.

${ }^{6}$ ) University of Banja Luka, Faculty of Forestry, Bulevar vojvode Stepe Stepanovića 75a, 78000 Banja Luka, Bosnia and Herzegovina.

$\left.{ }^{7}\right)$ University of Belgrade, Institute for Biological Research Siniša Stanković, Department of Evolutionary Biology, Bulevar Despota Stefana 132, 11000 Belgrade, Republic of Serbia.

$\left.{ }^{8}\right)$ Thünen-Institute for Forest Genetics, Grosshansdorf, Germany, Sieker Landstr. 2, D-22927 Großhansdorf, Germany.

*) Corresponding author: SRĐAN StojNić. University of Novi Sad, Institute of Lowland Forestry and Environment, Antona Čehova 13d, 21000 Novi Sad, Serbia. Phone: +38121540382, Fax: +38121540385. E-Mail: srdjan.stojnic@uns.ac.rs. variance showed that effects of provenance, site, and $\mathrm{P} \times \mathrm{S}$ interaction are highly significant $(p<0.001)$ in both age groups. Linear regression model evidenced that most of the provenances had regression coefficients not significantly different from unity $(b=1.0)$, except for provenances Sjeverni Dilj Caglinski (HR24) and Vranica-Bistrica (BA59). The partitioning of the total sum of squares (SS) exhibited that the site effect was the predominant source of variation in both age groups of provenances $(50.7 \%$ and $38.5 \%$, respectively). Additionally, regression analysis explained $15.8 \%$ and $33.2 \%$ of provenance by site interaction terms, in provenances age six and five years, respectively, while the AMMI analysis accounted for $62.2 \%$ and $78.7 \%$ in $\mathrm{P} \times \mathrm{S}$ interaction. The results of AMMI showed that the first principal component (PC1) was statistically significant in both age groups. Adaptability and stability of provenances to the test sites were estimated with AMMI1 and AMMI2 biplots. Provenance Sjeverni Dilj Caglinski (HR24) showed constant performance over tested sites, characterizing with aboveaverage height growth at low yielding environments. Provenances HR25 and BA61 showed the opposite type of adaptation, being adapted to high yielding sites. Provenance Valkonya (HU42) was characterized by IPCA1 score close to zero and above average mean height growth, suggesting general adaptation to the tested environments. The implication of $\mathrm{P} \times \mathrm{S}$ was discussed in light of impact of climate change on beech and selection of most suitable provenances for future reforestation programs.

Key words: European beech, provenance trial, provenance $\times$ site interaction, linear regression model, AMMI analysis, biplot.

\section{Introduction}

European beech (Fagus sylvatica L.) is one of the main tree species in Europe. Covering an 
area of approximately 14 million ha (VON WUEHLISCH, 2010a), beech is ecologically and economically one of the most important species for European forestry. Due to its known sensitivity to drought, beech is threatened by climate change. It is assumed that most endangered beech populations are those at the southern limit of the species distribution (JUMP et al., 2006). On the other hand, in large parts of temperate and boreal regions, natural conifer forests (e.g. Norway spruce stands) are supposed to be replaced with the more competitive European beech forests (BUGMANN, 1997; AMmer et al., 2008).

Provenance trials may provide a good basis for evaluation of genetic diversity and potential of various provenances to adjust to given climate conditions (STOJNIC et al., 2013a). Recent studies demonstrated that beech populations from Southern Europe might be potential targets in the search for drought-resistant ecotypes (THIEL et al., 2014). For example, RoBSoN et al. (2013) showed that southern provenances from Spain and Bulgaria maintained high rates of assimilation even in mid-summer, whereas provenances from cooler sites in central and north Europe demonstrated reduced photosynthetic capacity under such conditions. Similarly, studying physiological differences of beech provenances exposed to drought stress, DounAVI et al. (2016) reported that Greek population showed better adaptability to future environmental conditions in comparison with provenances from central Europe.

International beech provenance trials were established in five series in 1986, '87, '89, '95 and '98 (vON WuEHLISCH, 2004). Unfortunately, within these series, the provenances from the central Balkan region (Bosnia and Herzegovina, and Serbia) were omitted, while the provenances from Croatia were poorly represented. Due to the expected genetic variation in this region, new trial series were established in order to cover this area (VON WUEHLISCH, 2004). The most recent series of international beech provenance trials were established in 2007. For this purpose, seven provenance trials were established across a range of environments: Bosnia and Herzegovina, Croatia, Italy, Germany (2) and Serbia (2), involving 32 provenances from eight countries (VON WUEHLISCH et $a l ., 2010 b)$. Contrary to previously established series, this was the first time that the majority of the provenances originated from the Balkan region (20 provenances). Such an approach provided the opportunity to compare performance in the field trials among the Balkan provenances and provenances originating from the core of Europe. Due to the fact that experiments were established across several sites, it also provided possibility to assess genotype by environment interaction $(\mathrm{G} \times \mathrm{E})$. The magnitude of $\mathrm{G} \times \mathrm{E}$ interaction is essential in a tree breeding programs for decision making about testing and deployment strategies (PSWARAYI et al., 1997; ZAS et al., 2004). Thus, the key objective in studies of $\mathrm{G} \times \mathrm{E}$ interaction is the assessment of stability and adaptability of provenances against a series of stressors that prevail at given environments.

Analysis of variance (ANOVA) is certainly the most frequently used method for studying $\mathrm{G} \times \mathrm{E}$ interaction, besides regression models and multivariate techniques (HANNRUP et al., 2008). It is primarily used in determination and testing of sources of variability (e.g. genotype, environment, $\mathrm{G} \times \mathrm{E}$ interaction). However ANOVA allows adequate interpretation of main effects, it does not offer the insight into the response of the genotypes in the non-additive (interaction) term (SHAFII and PRICE, 1998; ZoBEL et al., 1988). In other words, ANOVA does not provide information about the performances of single genotype against environmental variations (Аввотт et al., 2012). Thus, it is necessary to apply other methods to identify interaction relationships.

Linear regression analysis was reviewed by numerous authors (FINLAY and WILKINSON, 1963; Eberhart and Russell, 1966; Perkins and JINKs, 1968, etc.). The method is based on the regression of genotypic means against the mean values of an environmental effect at each site (environmental index), and could be used for the identification of good general performers across a wide range of sites (FINLAY and WILKINSON, 1963; MATHESON and RAYMOND, 1986). This approach is widely used in plant breeding, although the analysis has several limitations. Crossa (1990) provided a comprehensive review of statistical and biological limitations of regression analysis in studying of $\mathrm{G} \times \mathrm{E}$ interaction.

The most commonly used multivariate technique is additive main effects and multiplicative interaction method (AMMI) (Bose et al., 2014a). AMMI analysis integrates analysis of variance and principal components analysis 
(PCA) into a unified approach (GAUCH, 1988). AMMI has several models: AMMIO which estimates additive main effects of genotypes and environments and does not include any principal component axis (IPCA); AMMI1 which combines additive main effects from AMMI0 with provenance by site interaction effect estimated from the first principal component axis (IPCA1); AMMI2 which combines additive main effects plus interaction effect for axes 1 and 2 (IPCA1 versus IPCA2), and so forth, until the full model with all IPCA axis (GAUCH, 1988). Principal component analysis-based biplots were used in numerous studies due to easy visualization of responses and relationships (RAMBURAN et al., 2011). In most cases, AMMI1 and AMMI2 biplots were selected for graphical assessment of provenance adaptability and stability.

Studies on genotype by environment interaction and stability analysis were used intensively in breeding programs of agricultural crops (BABIĆ et al., 2010; MOHAMMADI and AMRI, 2011; KARIMIZADEH et al., 2012; Bose et al., 2014b), even though numerous experiments were performed on forest tree species, as well. Apart from the most frequently studied growth parameters (PSWARAYI et al., 1997; KARLSSON and HoGBerg, 1998; ZAS et al., 2004; HANNRUP et al., 2008; RWEYONGEZA et al., 2011), analyses of genotype by environment interaction in forest tree species successfully implemented other traits, e.g. fruit mass (LITTVAY, 2011), wood chemical properties (SYKES et al., 2006), stem and crown form (FALKENHAGEN, 1996), wood density (BALTUNis et al., 2009), and water use efficiency (PONTON et al., 2002).

Due to certain statistical and biological limitations of above mentioned methods, it is suggested that $\mathrm{G} \times \mathrm{E}$ interaction should be quantified using at least two different approaches together (KIM et al., 2008). Therefore, in the present study, FINLAY and WILKINsON's regression analysis and AMMI model were adopted in order to: a) examine the influence of provenance, site and provenance by site interactions on height growth of fifteen European beech provenances, and b) determine adaptability and stability of certain provenances for height growth across test sites. The results were discussed in terms of climate change impact on beech and selection of suitable provenances for future reforestation programs in different regions.

\section{Material and methods}

Provenance by site interaction $(\mathrm{P} \times \mathrm{S})$ of 15 European beech (Fagus sylvatica L.) provenances, growing in common garden experiments, was analyzed to identify stable provenances with good height growth in juvenile stage of development (Fig. 1). The provenances were grown at four test sites, established in Bosnia and Herzegovina (Kakanj), Croatia (Medvednica) and Serbia (Fruska Gora and Debeli Lug) (Tab. 1).

Trial site Kakanj is situated in the region that belongs to temperate continental climate, characterized by cold winters and moderately warm summers, with high level of precipitation. The climate on the Medvednica mountain is temperate continental, as well, typical for Central European mountain region. In comparison to the surrounding lowland area, the mountain behaves as an „island“ in its climate characteristics, with more precipitation, lower temperatures, longer duration and greater snow cover. As for the trial localities in Serbia, both sites are under the influence of temperate continental climate (STOJNIĆ et al., 2012). Fruska Gora Mountain is located in the Northern part of Ser-

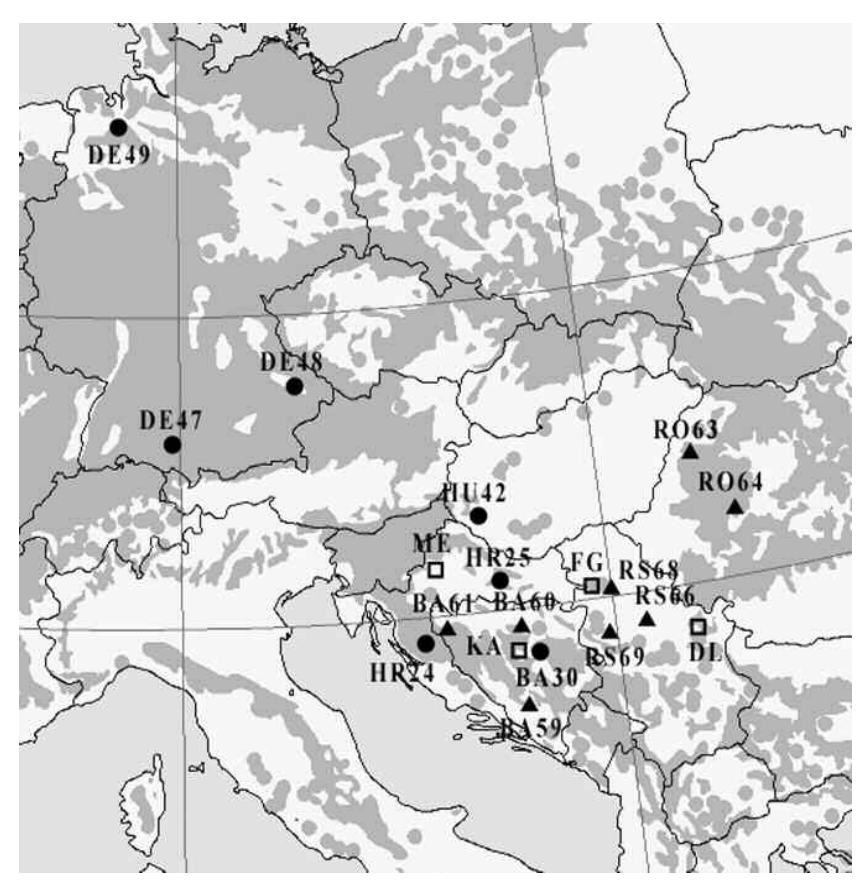

Figure 1. - The distribution of European beech provenances involved in the study. The abbreviation indicates six-year-old provenances (•), five-year-old provenances $(\boldsymbol{\Delta})$ and trial sites $(\square)$ as shown in Tab. 1 and Tab. 2. The dark shaded area represents natural distribution range of beech (VON WUEHLISCH, 2008). 
bia. Similarly to Medvednica, the mountain appears as an "island" and it is surrounded by lowland agricultural land and floodplain forests of pedunculate oak and poplar plantations.
Debeli Lug is located in Northeastern part of Serbia. According to KRSTIĆ et al. (2002), 27\% of pure beech forests in Serbia are situated in this region.

Table 1. - General data about four sites of European beech provenance trials.

\begin{tabular}{|c|c|c|c|c|c|c|c|}
\hline Abbrev. & Locality & Country & Latitude & Longitude & $\begin{array}{l}\text { Alitude } \\
\qquad(\mathrm{m})\end{array}$ & $\begin{array}{l}\text { Mean amnual air } \\
\text { temperature }\left({ }^{\circ} \mathrm{C}\right)\end{array}$ & $\begin{array}{l}\text { Arinual sum ol } \\
\text { precipitation (mm) }\end{array}$ \\
\hline $\mathrm{KA}$ & Kakanj & 3osnia & $44^{\circ} 04^{\prime}$ & $18^{\circ} 11^{\prime}$ & 538 & 10.7 & 960 \\
\hline $\mathrm{ME}$ & Medvednica & Croatia & $45^{\circ} 53^{\prime}$ & $15^{\circ} 55^{\prime}$ & 730 & 6.6 & 1240 \\
\hline $\mathrm{FG}$ & Fruska Gora & Scrbia & $45^{\circ} 10^{\prime}$ & $19^{\circ} 47^{\prime}$ & 366 & 11.0 & 624 \\
\hline DL & Debeli Lug & Serbia & $44^{\circ} 19^{\prime}$ & $21^{\circ} 52^{\prime}$ & 742 & 8.8 & 829 \\
\hline
\end{tabular}

Table 2. - European beech provenances in the study.

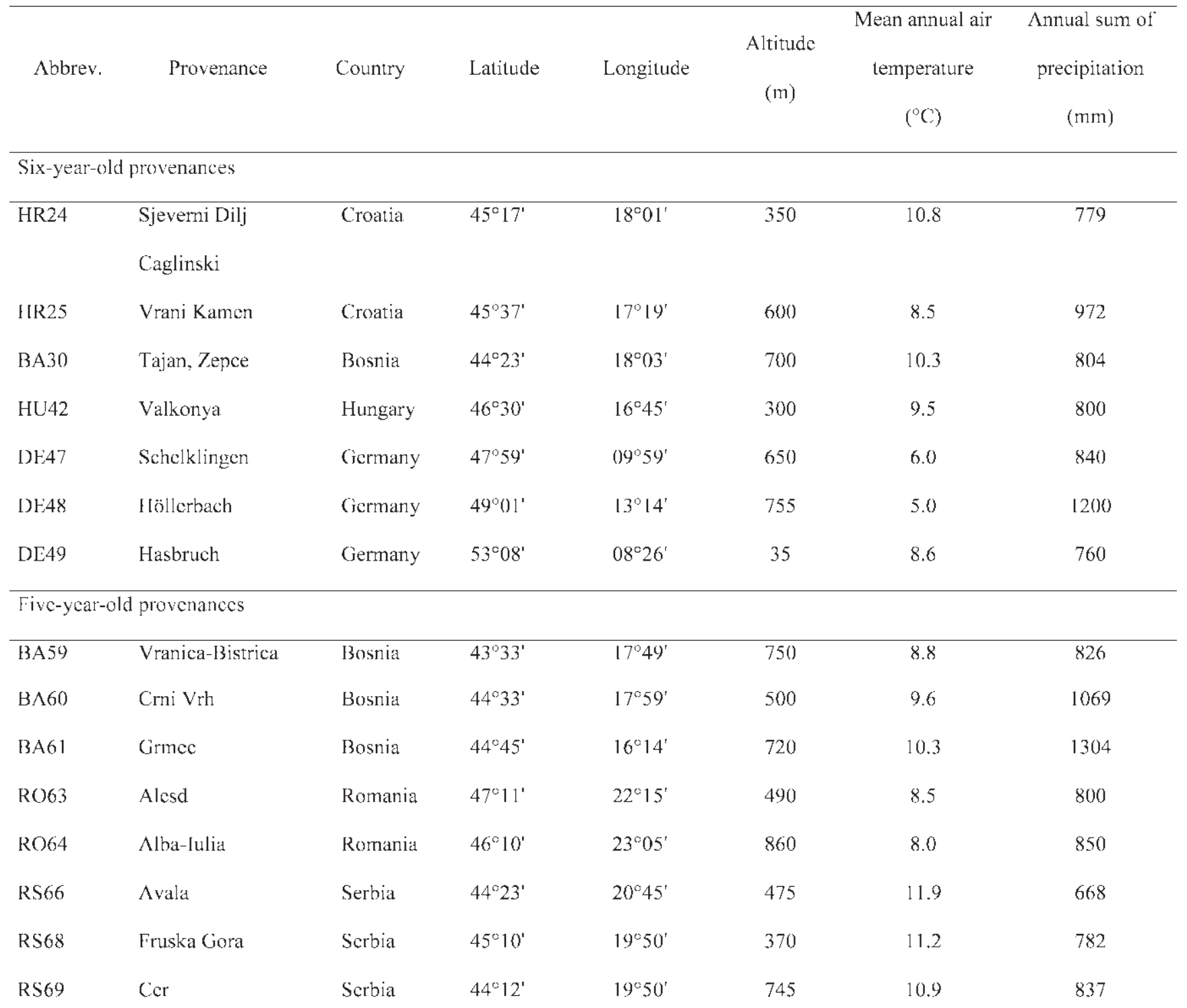


The trials were established in spring 2007 by planting 2- and 3-year-old saplings. They were arranged in a randomized complete block design replicated three times. Fifty saplings per plot were planted with $1 \times 2 \mathrm{~m}$ spacing. The saplings were grown and distributed by the Thünen-Institute for Forest Genetics in Grosshansdorf, Germany. Survival and height of all plants at each site were obtained from measurements conducted in 2009, which involved provenances of both ages (7 provenances were 6 years old, whereas 8 provenances were 5 years old). For that reason, we classified provenances into two age groups and analyzed them separately (Tab. 2).

The first group of provenances (the „older“ group) consisted of geographically distant provenances, representing different geographic origins, covering a gradient in climate conditions from the North to the South of Europe. In contrast to the first group, the second, „younger“ group, was more homogenous with respect to the provenances' geographic origin, as it included only South-eastern provenances two provenances from Romania and three provenances from Bosnia and Serbia, respectively. Although aforementioned provenance trials were established from more than 20 provenances each, the present study involved only provenances that were common for all trials.

In order to evaluate adaptability and stability of beech provenances in different environments, the data of provenance height were subjected to linear regression models (FINLAY and WILKINson, 1963) and Additive main effects and multiplicative interaction analysis (AMMI model).

Simple linear regression is one of the most frequently used statistical approach in genetics and plant breeding (Crossa, 1990). In this model, the regression coefficient (b) of the geno-

Table 3. - Mean percentage survival of provenances at Kakanj (BA), Medvednica (HR), Fruska Gora (RS) and Debeli Lug (RS).

\begin{tabular}{|c|c|c|c|c|c|}
\hline Provenance & Kakanj & Medvednica & Iiruska Gora & Debeli Lug & Vean \\
\hline \multicolumn{6}{|c|}{ Six-year-old provenances } \\
\hline IIR24 & 87.3 & 87.3 & 86.0 & 96.0 & 89.2 \\
\hline HR25 & 84.0 & 98.7 & 90.3 & 92.7 & 91.4 \\
\hline $\mathrm{BA} 30$ & 73.3 & 96.7 & 92.0 & 98.3 & 90.1 \\
\hline HL 42 & 85.3 & 95.3 & 94.7 & 98.0 & 93.3 \\
\hline DL47 7 & 82.7 & 94.7 & 92.3 & 94.3 & 91.0 \\
\hline DE48 & 74.0 & 92.0 & 96.0 & 90.3 & 88.1 \\
\hline DE49 & 90.7 & 94.0 & 88.7 & 94.0 & 91.9 \\
\hline \multicolumn{6}{|c|}{ Five-year-old provenances } \\
\hline BA59 & 43.3 & 75.3 & 86.0 & 84.0 & 72,2 \\
\hline BA60 & 50.0 & 70.0 & 84.7 & 78.7 & 70.9 \\
\hline BA61 & 75.3 & 81.3 & 90.0 & 94.0 & 85.2 \\
\hline $\operatorname{RO} 63$ & 75.7 & 64.7 & 76.0 & 82.3 & 74.7 \\
\hline RO64 & 53.3 & 80.0 & 78.0 & 90.0 & 75.3 \\
\hline RS66 & 72.0 & 79.3 & 80.3 & 90.0 & 80.4 \\
\hline RS68 & 71.0 & 64.7 & 78.0 & 90.3 & 76.0 \\
\hline
\end{tabular}


types is used to determine the stability of genotypes over environments. Slope or b coefficient is interpreted as the amount of change in the dependent variable that is associated with a change in one unit of the independent variable. According to FINLAY and WILKINSON (1963) mean height of entries, across all environments, and regression coefficients are important indicators of genotype adaptation. The linear regression model equation is (eqn. 1):

$$
Y_{i j}=\mu+g_{i}+E_{j}+b_{i} E_{j}+e_{i j}
$$

where $Y_{i j}$ is the mean of provenance $i$ in environment $j ; \mu$ is the general mean; $g_{i}$ is the mean of provenance $i$ over all environment; $E_{j}$ is the environmental index for environment $j\left(\mathrm{Y}_{. j}-\right.$ $\mathrm{Y} ..) ; b_{i}$ is the slope of regression specific for provenance $i$; and $e_{i j}$ is the residual variation which is assumed to be zero for the values averaged over replications (KIM et al., 2008).

AMMI partitions the overall variation into genotype main effects $(G)$, environment main effects (E) and genotype environment (GEI) effects and utilize principal components analysis (PCA) to study $\mathrm{G} \times \mathrm{E}$ (KARIMIZADEH et al., 2012). The AMMI model equation is (eqn. 2):

$$
Y_{i j}=\mu+G_{i}+E_{j} \sum_{n=1}^{N} \lambda_{i} \gamma_{i n} \delta_{j n}+e_{i j}
$$

where, $Y$ is the height of the $i^{\text {th }}$ genotype in the $j^{\text {th }}$ environment; $\mu$ is the overall mean; $G_{i}$ is the $i^{\text {th }}$ genotype main effect; $E_{j}$ is the $j^{\text {th }}$ environment main effect; $\lambda_{i}$ is the singular value of $n^{\text {th }}$ PCA axis; $\gamma_{i n}$ is the genotypic eigenvector values for $n^{\text {th }}$ PCA axis; $\delta_{j n}$ is the environmental eigen-vector values for $n^{\text {th }}$ PCA axis and $e_{i j}$ is the residual (KIM et al., 2008).

To test the significance of $\mathrm{G} \times \mathrm{E}$ effects, data pooled across the four sites were analyzed using analysis of variance (ANOVA) in program Statistica for Windows Version 12 (StatSoft, Inc.). Linear regression and AMMI analyses were performed using SAS version 9.1.3 (SAS Institute, Cary, NC 2011). The biplots were created in order to provide simple and effective means of illustrating the $\mathrm{P} \times \mathrm{S}$ interaction. The AMMI1 biplot was generated from main effects of provenances and environments and the IPCA1 scores. The abscissa shows the main effects and the ordinate shows the IPCA1 scores that capture interaction effects (ODEWALE et al., 2013).
AMMI2 biplots were produced to visualize the $\mathrm{P} \times \mathrm{S}$ interactions for height growth. AMMI2 biplots are characterized by the projection of the genotype and environment IPCA1 and IPCA2 scores onto a two-dimensional biplot (RAMBURAN et al., 2011). The genotypic IPCA scores in the AMMI analysis are considered indicators of the yield stability (PURCHASE $e t a l$., 2000).

\section{Results and discussion}

\section{Survival of plants}

The survival percentage of provenances varied considerably from trial to trial. The lowest survival percentage was observed at the trial site Kakanj (72.7\%), whereas the highest percentage was recorded at the trial Debeli Lug $(90.9 \%)$. Lower mean survival rate observed in Bosnian trial was mainly the consequence of surprisingly low survival rate of five-year-old provenances BA59, BA60 and RO64 (43.3\%, $50.0 \%$ and $53.3 \%$, respectively). Provenance HU42 characterized with the highest survival percentage $(93.3 \%)$. Among the five-year-old provenances notably higher survival percentage was observed in provenances BA61 and RS66 ( $85.2 \%$ and $80.4 \%$, respectively).

\section{Stability from Finlay and Wilkinson's linear regression analysis}

Results of the present study showed significant provenance effect $(p<0.001)$ for height growth of seedlings in both age groups, which was probably the result of differences in the genetic makeup of the studied provenances (Tab. 4).

Significant effects of site $(\mathrm{p}<0.001)$ and provenance by site interaction $(\mathrm{p}<0.001)$ in both age groups indicated high phenotypic plasticity of height growth and existence of genetic variation in plastic response to environmental conditions. This is in agreement with the results of other studies on growth parameters in these beech provenance trials (JEZBEC et al., 2007; IVANKOVIĆ et al., 2011). As for the linear regression model, the regression line was not significant in six- and five-year-old provenances, probably because different environments were affected by different factors (ALIA et al., 2010). The partitioning of total sum of squares (SS) exhibited that the site effect was a predominant 
Table 4. - Two-way ANOVA for height growth with site regression among six-year-old and fiveyear-old provenances.

\begin{tabular}{|c|c|c|c|c|c|}
\hline Source & $d f$ & SS & MS & $F<P$ & $\%$ of SS \\
\hline \multicolumn{6}{|l|}{ Six-ycar-old } \\
\hline Provenance (P) & 6 & 1413.13 & 235.52 & $<0.001$ & 33.5 \\
\hline Site $(S)$ & 3 & 2141.12 & 713.71 & 0.001 & 50.7 \\
\hline $\mathrm{P} \times \mathrm{S}$ & 18 & 608.96 & 37.16 & $<0.00 \mathrm{I}$ & 15.8 \\
\hline $\mathrm{P} \times \mathrm{S}$ rcgrcssion & 6 & 375.99 & 62.66 & ns & (56.2) \\
\hline Deviation & 12 & 292,97 & 24.41 & & $(43.8)$ \\
\hline Total & 27 & 4223.21 & & & 100.0 \\
\hline \multicolumn{6}{|l|}{ Five-year-old } \\
\hline Provenance $(\mathrm{P})$ & 7 & 1122.81 & 160.40 & $<0.001$ & 28.3 \\
\hline Site (S) & 3 & 1530.25 & 510.08 & $<0.001$ & 38.5 \\
\hline$P \times S$ & 21 & 1317.83 & 62.75 & $<0,00 \mathrm{l}$ & 33.2 \\
\hline$P \times S$ regression & 7 & 163.57 & 23.37 & $\mathrm{~ns}$ & (12.4) \\
\hline Deviation & 14 & 1154.26 & 82.45 & & $(87.6)$ \\
\hline Tolal & 31 & 3970.89 & & & 100.0 \\
\hline
\end{tabular}

Legend: ns - not significant at $\mathrm{p}<0.05$.

source of variation in both age groups of provenances $(50.7 \%$ and $38.5 \%$, respectively). The interaction term explained $15.8 \%$ and $33.2 \%$ of the total variation, in provenances at ages of six and five years, respectively. The greater sum of squares of the $\mathrm{P} \times \mathrm{S}$ term compared to the effects of provenances $(28.3 \%)$, observed in the „younger" group of provenances, indicates larger differences in provenance response across environments than in the "older" group of provenances (REZENE et al., 2014).

Regression coefficients for most of the provenances were not significantly different from unity $(b=1.0)$, except for provenances HR24 (0.158) and BA59 (1.371) (Tab. 5).

Provenance HR24 showed constant performance over environments, with very small changes in mean height despite substantial changes in environments. It means that this provenance was characterized by above average height growth in low yielding environments, yet insensitive to environmental change and with relatively small height growth in high yielding environments. Contrary to this, another prove- nance from Croatia (HR25) exhibited the opposite type of adaptation. This provenance was characterized by high mean plant height and regression coefficient higher than 1.0 (1.454), indicating a better than average response to favorable environments, but worse than average response to unfavorable environments (below average stability). In the "younger" group provenances BA59 (1.371), BA61 (1.492) and RS66 (1.345) exhibited a similar pattern of response. In these provenances small changes in the environment caused large changes in tree height (FINLAY and WiLKINSON, 1963). Hence, these provenances can be described as specifically adapted to high-yielding environments. The provenance from Hungary (HU42) was characterized by above average height and regression coefficient close to 1.0 (0.959) showing an average stability over all environments. This indicates that the response of this provenance to diverse environments is the same as the average response of all provenances in the experiment. In other words, it indicates that it has general adaptability. Finally, provenances RO63, RO64 and RS69 characterized by below 
Table 5. - The mean height of provenances, slopes of regression of provenance means on site index and standard error of slopes.

\begin{tabular}{|c|c|c|c|}
\hline Provenance & Mcan height (cm) & Slope & Standard error \\
\hline \multicolumn{4}{|c|}{ Six-year-old provenances } \\
\hline IIR24 & 96.93 & $0.158 *$ & 0.122 \\
\hline HR25 & 103.39 & 1.454 & 0.326 \\
\hline $\mathrm{BA} 30$ & 103.63 & 0.833 & 0.250 \\
\hline HU42 & 97.67 & 0.959 & 0.209 \\
\hline DГ:47 & 85.37 & 1.398 & 0.131 \\
\hline DE 48 & 84.90 & 0.867 & 0.390 \\
\hline DE49 & 93.32 & 1.331 & 0.287 \\
\hline \multicolumn{4}{|c|}{ Five-year-old provenances } \\
\hline BA59 & 78.61 & $1.371 *$ & 0.011 \\
\hline $\mathrm{BA} 60$ & 79.91 & 0.808 & 0.720 \\
\hline BA61 & 77.63 & 1.492 & 1.230 \\
\hline $\mathrm{RO} 63$ & 66.14 & 0.600 & 0.444 \\
\hline $\mathrm{RO} 64$ & 66.29 & 0.811 & 0.518 \\
\hline RS66 & 82.27 & 1.345 & 0.405 \\
\hline $\mathrm{RS} 68$ & 76.11 & 0.913 & 0.578 \\
\hline RS69 & 69.55 & 0.659 & 0.147 \\
\hline
\end{tabular}

Legend: * - slopes significantly different from 1.00 .

average mean heights and regression coefficient less than $1.0(0.600,0.811$ and 0.659 , respectively), which points to poor adaptability to all trial sites.

\section{Adaptability from AMMI model}

While the regression analysis explained $15.8 \%$ and $33.2 \%$ of provenance by site interaction, the AMMI analysis accounted for $62.2 \%$ and $78.7 \%$ of $\mathrm{P} \times \mathrm{S}$ interaction in six- and fiveyear-old provenances, respectively (Tab. 6).

These results are in agreement with the findings of PURCHASE et al. (2000), who compared several stability analysis procedures and concluded that AMMI analysis provides more adequate biological and statistical explanation of
$\mathrm{G} \times \mathrm{E}$ interaction than Finlay and Wilkinson regression analysis.

In the AMMI1 biplot, the $\mathrm{x}$-axis represents the main effects (means) and y-axis represents the effects of the interaction (IPCA1) (MIROsAVLJEVIC et al., 2014). Fig. 2 represents the AMMI1 biplot of PCA axis 1 versus mean height growth $(\mathrm{cm})$ of both provenances and environments. The figures illustrate wide discrepancy between the variability of environments and genotypes.

Stable provenances (with less GEI) are those which have IPCA1 values closer to zero regardless of their sign. The best provenances are those placed on the right side of the AMMI1 biplot origin - the junction of IPCA1 at zero and 
the mean height. Moreover, provenances appearing closer to the vertical reference line at IPCA $1=0$ indicate greater relative stability (SHAFII and PRICE, 1998). Concerning the „older“ group of beech provenances, there was clear separation of German provenances (DE47, DE48 and DE49) on the left side of the AMMI1 biplot and the rest of provenances on the right (Fig. 2). Hence, it can be concluded that German provenances showed below average performances in the environmental conditions of Southern Europe (Balkan Peninsula). Similar results were reported by VIŠNJIĆ (2010) who conducted the research on 16, nine-years-old beech provenances originating from Bosnia, Germany, Italy, Romania and Slovenia. The author demonstrated that beech provenances from Southern part of distribution range showed better height growth in comparison to Northern provenances. This phenomenon might be the result of a strong local adaptation of Northern provenances to environmental conditions at the place of their origin or, rather, maladaptation to the environments in Southern Europe. Provenance HU42 was characterized by IPCA1 score close to zero and above average mean height growth, reflecting general adaptation to the tested environments. According to AliA et al. (2010), existence of provenances that perform better across a range of different environments, points to caution in some generalizations on local adaptation in beech. The locality Fruska Gora was quite distinct from the other sites by its large interaction score (+3.83). Other sites had smaller and negative interaction scores. Regarding the "younger" group of provenances, IPCA1 values close to zero were shown by provenances BA59 and RS69, although their position in the AMMI1 biplot was on the opposite sides along the $\mathrm{x}$-axis

Table 6. - Combined ANOVA with AMMI model for height growth among six-year-old and fiveyear-old provenances.

\begin{tabular}{|c|c|c|c|c|c|}
\hline Source & $\mathrm{df}^{\circ}$ & SS & MS & F value & $\%$ of $\mathrm{P} \times \mathrm{SSS}$ \\
\hline \multicolumn{6}{|l|}{ Six-year-old } \\
\hline Provenance (P) & 6 & 1413.13 & 235.52 & & \\
\hline Site $(S)$ & 3 & 2141.12 & 713.71 & & \\
\hline$P \times S$ & 18 & 668.96 & 37.16 & & \\
\hline IPCA 1 & 8 & 415.81 & 51.98 & $2.053 *$ & $(62.2)$ \\
\hline $\operatorname{IPC} \wedge 2$ & 6 & 157.80 & 26.30 & $1.103 \mathrm{~ns}$ & $(23,6)$ \\
\hline $\mathrm{P} \times \mathrm{S}$ residual & 4 & 95.15 & 50.14 & & $(14.2)$ \\
\hline Total & 27 & 4223.21 & & & \\
\hline \multicolumn{6}{|l|}{ Five-year-old } \\
\hline Provenance $(\mathrm{P})$ & 7 & 1122.81 & 160.40 & & \\
\hline Site (S) & 3 & 1530.25 & 510.08 & & \\
\hline $\mathrm{P} \times \mathrm{S}$ & 21 & 1317.83 & 62.75 & & \\
\hline IPCA 1 & 9 & 1037.31 & 115.26 & $4.930 *$ & $(78.7)$ \\
\hline IPCA 2 & 7 & 197.90 & 28.27 & $1.711 \mathrm{~ns}$ & $(15.0)$ \\
\hline$P \times S$ residual & 5 & 82.61 & 16.52 & & $(6.3)$ \\
\hline 'rotal & 31 & 3970.89 & & & \\
\hline
\end{tabular}

Legend: $* \mathrm{p}<0.05 ; * * \mathrm{p}<0.01 ; \mathrm{ns}-$ not significant at $\mathrm{p}<0.05$. 
(Fig. 2). Site Fruska Gora had the largest positive $(+4.42)$ and Debeli Lug the largest negative $(-3.53)$ score, in comparison to the other sites that displayed lower values of interaction scores.

The AMMI2 biplot (IPCA1 versus IPCA2 biplot) exhibits the magnitude of interactions of each provenance and environment (Fig. 3).

The environments with long vectors had greater influence in determination of provenance by site interaction and environments with short vectors contributed less to $\mathrm{P} \times \mathrm{S}$ (FARSHADFAR et al., 2012). Also, the angles between the environmental vectors in the biplot represent the phenotypic correlation between the environments (MOHAMMADI and AMRI, 2011). Smaller angle between interaction vectors indicates greater similarity in the interaction response (BABIĆ et al., 2010). Our results showed that sites Fruska Gora (RS) and Medvednica (HR) had the greatest influence on determination of $\mathrm{P} \times \mathrm{S}$, in both age groups of provenances. Also, smaller angle between environmental vectors of sites Kakanj (BA) and Debeli Lug (RS) indicates greater phenotypic correlation between these environments, especially for six-year-old provenances. Highly posi- tively correlated vectors indicate that provenances had similar responses and rank positions in these two sites. Conversely, non-correlated vectors (angles approaching $90^{\circ}$ ) or highly negatively correlated vectors (angles approaching $180^{\circ}$ ) indicate that provenances respond differently at sites (MURILLO, 2001). Provenance trial Fruska Gora exhibited strong negative correlation with vectors of other test sites. The provenances and environments with IPCA values of same sign show positive interaction, suggesting adaptation of provenances to those environments and the opposite (KIM et al., 2008). Also, provenances positioned closer to the biplot origin have higher stability (MIROSAVLJEVIC et al., 2014). Within the "older" group, provenances DE47, DE49 and HR25 expressed high interaction with the locality Fruska Gora, and therefore better adaptation to this site (Fig. 3). Unlike German provenances, provenance HR25 showed above average height growth, demonstrating specific adaptability to high yielding sites. On the other hand, provenances DE48 and BA30 showed high interaction with site Kakanj. Position of provenance HU42 closer to the biplot origin indicates higher stability of this provenance, which is already observed by AMMI1 biplot and linear a) Six-year-old provenances

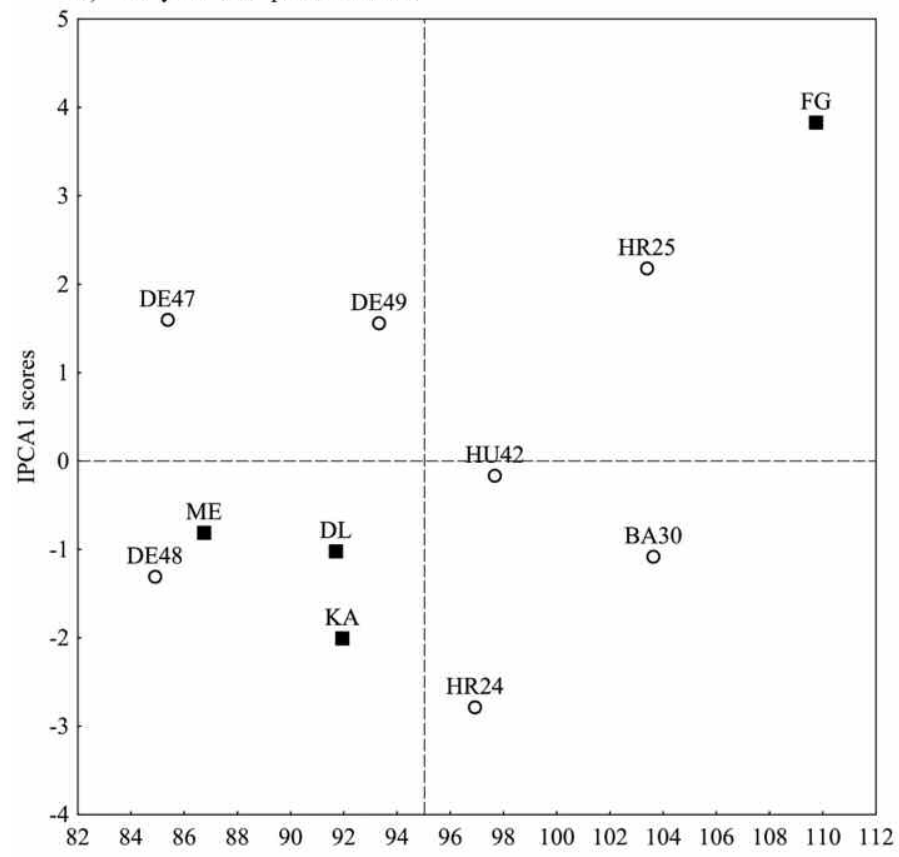

b) Five-year-old provenances

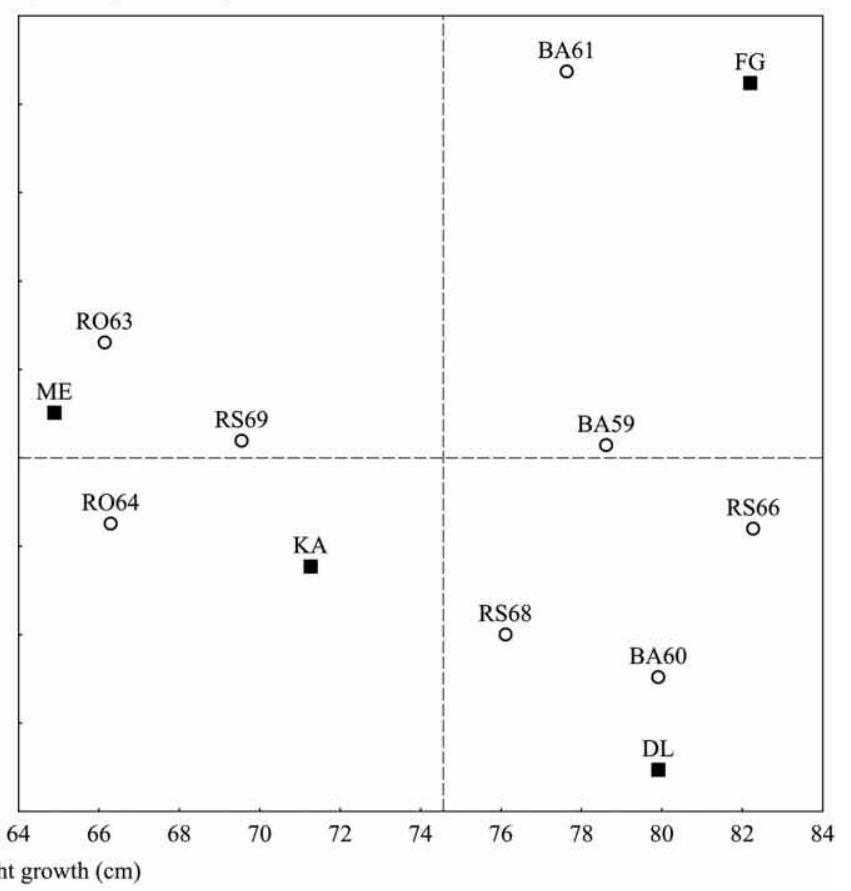

Figure 2. - AMMI1 biplot of mean height (cm) and IPCA1 scores of tested beech provenances across four environments, among: a) seven six-year-old and b) eight five-year-old provenances. The abbreviation indicates test sites (ם) and provenances (O) as shown in Tab. 1 and Tab. 2. The vertical dash line is the grand mean of experiment and the horizontal dash line is IPCA $=0$. 
a) Six-year-old provenances

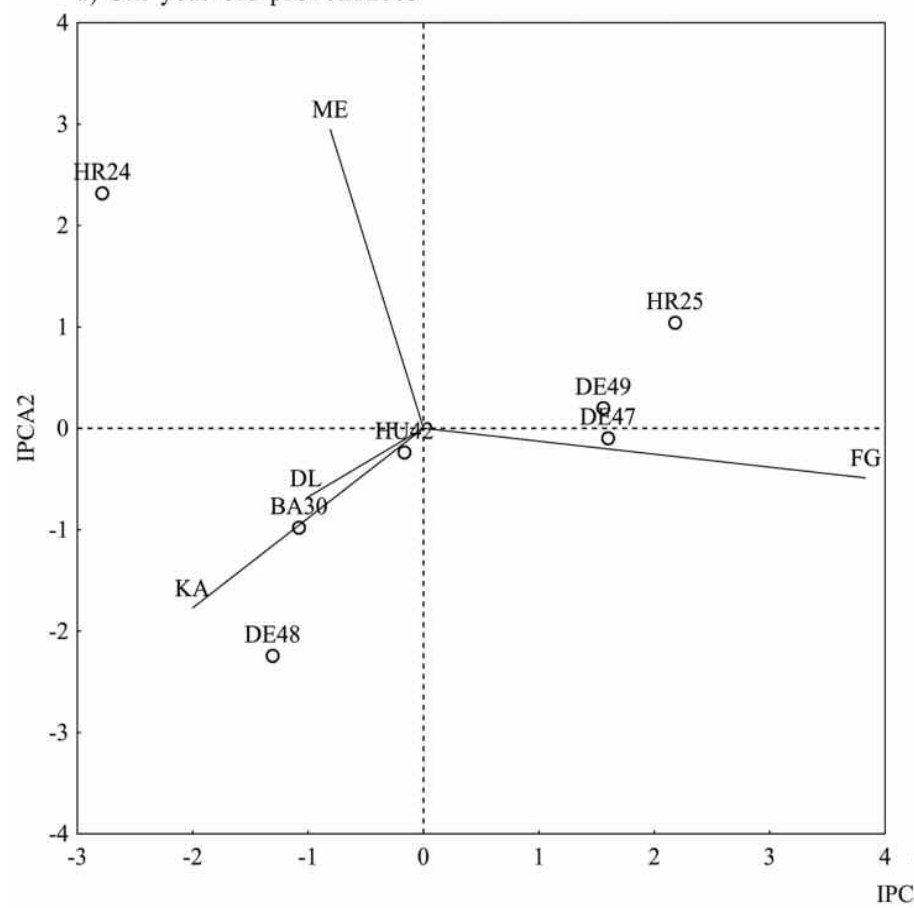

b) Five-year-old provenances

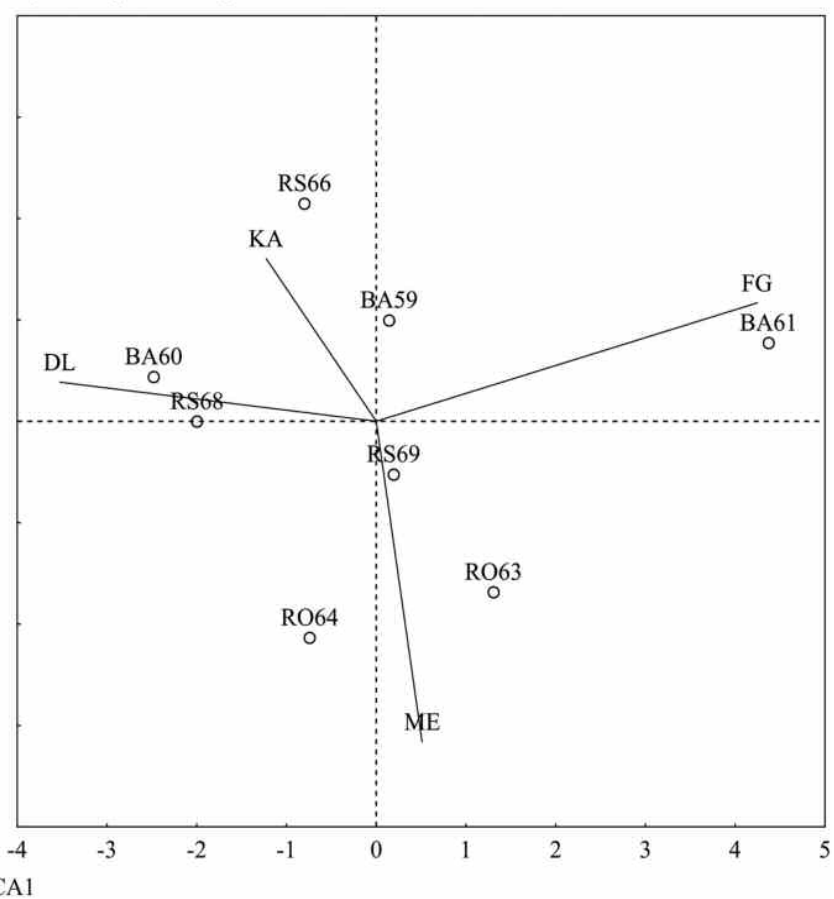

Figure 3. - Interaction biplot for the AMMI2 model on height growth among: a) seven six-year-old and b) eight five-year-old provenances, grown in four environments. The abbreviations represent the test sites and provenances as shown in Tab. 1 and Tab. 2.

regression analysis. Among the provenances which belong to "younger" group, provenance BA61 showed high interaction with Fruska Gora, provenances RO63 and RO64 with site Medvednica, provenances BA60 and RS68 with Debeli Lug and BA59 and RS66 with site Kakanj, pointing out their narrow adaptability to certain environments (Fig. 3).

\section{Implication of provenance by site interaction in light of climate change impact on beech}

Two general approaches were proposed to deal with genotype by environment interaction (RAYMOND and NAMKOONG, 1990; ZAS et al., 2004). The first approach is to define breeding zones with relatively uniform impact on genotypes and then choose the best, specifically adapted genotypes for each zone, independently (McKeand et al., 1990; Baltunis et al., 2010). The second approach is to find stable genotypes and to use them across a range of environments (FInLAY and WilKinson, 1963). However, stability per se is not necessarily a positive factor and it is desirable only when associated with high mean yield (ADUGNA et al., 2011). Present study evidenced that Hungarian provenance Valkonya (HU42) showed average stability over tested environments, as well as above average mean height growth. This provenance also showed the highest survival percentage. Thus, provenance HU42 could provide a tradeoff between maximizing growth in one environment and ensuring resilience across a range of environments. However, selection for generally adapted provenances based on overall performance and stability across sites would reduce genetic diversity (ZAS et al., 2004) and thereby decrease capacity of species to adapt to ongoing climate changes (McLACHLAN et al., 2007). For that reason, introduction of new provenances should be seen as complementing local seed sources, and never as replacing local provenance. In such a manner, fitness of local population may be enhanced via gene flow and changes in the genetic composition (LENORMAND, 2002). Furthermore, presence of increased genetic diversity might ensure faster response to rapid climatic changes, which will allow forest trees to survive, adapt and evolve in new environments (KOSKELA et al., 2007).

Provenances HR25 and BA61 could be specifically adapted to high-yielding environments, as they showed the greatest height growth under the most favorable site conditions. These prove- 
nances demonstrated high survival percentage, as well. Recently, STOJNić et al. (2013a) evidenced that provenance HR25, growing at the Fruska Gora site, showed similar pattern in radial increment and wood anatomical structure as the local provenance, which points to a high potential of this provenance to adjust their wood-anatomical variables to these environmental conditions. However, because of low stability, performances of provenances HR25 and BA61 could be reduced under the influence of projected global warming, due to deterioration of site conditions for beech growth in Southeastern Europe (VON WuEHLISCH, 2004). Therefore, decision makers should decide whether to favor the provenances best adapted for current conditions or those for the expected future climatic conditions (LINDNER, 2007). For example, provenances occupying the sites characterized by certain climatic conditions, which might be expected to be similar to climate of other sites in the future (based on climate model predictions), should be considered as candidate sources for seed collection dedicated to those sites in the future (LINDNER et al., 2008). LINDNER et al. (2010) believe that beech populations from more southern latitudes may be a valuable pollen source in terms of increasing local adaptation at species level.

Climate change is projected to not only reduce productivity of beech stands, but also increase mortality in certain areas (EILMANN et al., 2014). Because of global warming, beech may no longer be adapted to the set of environmental conditions in a given natural range and could therefore fall outside its climatic niche (BELLARD et al., 2012). STOJANOVIĆ et al. (2013) demonstrated that compared to the present distribution of beech in Serbia, up to $90 \%$ of the beech forests may be located outside their $20^{\text {th }}$ century bioclimatic niche until the end of $21^{\text {st }}$ century. Therefore, the establishment of new forests with genotypes and/or provenances of the same species that are better adapted to changing conditions would be of primary importance (WORTEMANN et al., 2011). Results of the present study evidenced that Croatian provenance (HR24) was quite insensitive to environmental changes, showing potential of producing above average height growth in low yielding environments. This result confirms the findings of StojNić (2013b), who followed variability of certain physiological parameters in two beech provenance trials (Fruska Gora and Debeli Lug), over two growing seasons (wet and dry).
The author reported that despite the reduction of gas exchange in beech saplings during drought stress, provenance HR24 exhibited higher rates of stomatal conductance and net photosynthesis, compared to other provenances. Moreover, this provenance showed higher water use efficiency in comparison with other provenances involved in study. Owing to the fact that ability of plants to acclimate to different environmental conditions is directly or indirectly associated with their potential to adjust photosynthetic capacity to match those conditions (ATHANASIOU et al., 2010), gas exchange parameters are important indicators of vitality and competitive ability of species or single genotype at the particular site (ARANDA et al., 1996). Similarly, water use efficiency is considered an important component in assessment of plant drought resistance (BLUM, 2009). Bearing in mind these results, it is likely that provenance HR24 could be efficiently used in reforestation programs for more dry sites in Europe (e.g. sites in Southern Europe). CZAJKowski and BolTE (2005) recommended the introduction of drought-adapted provenances to decrease the vulnerability of Central European beech stands to drought.

Nevertheless, before making recommendations regarding seed transfer, meta-analysis of all existing beech provenance trials should be considered (LINDNER et al., 2008). Furthermore, at this early developmental stage, height growth does not fully reflect growth potential of the provenances and the effect of the local environment on the provenances. Several authors demonstrated that early growth assessments may not be reliable for predicting $\mathrm{G} \times \mathrm{E}$ at mature age (HOGBERG and KARLSSON, 1998; HANNERZ et al., 1999; GWAZE et al., 2001). Similarly, MuHs et al. (2010) consider that the growth potential of beech can be estimated reliably only after 60 years in the field. For that reason, it is too early to reach a conclusion regarding provenance potential (VON WUEHLISCH, 2004). Instead, long-term monitoring of height growth is required.

\section{References}

Abbott, L., S. Filippini, H. Delfino and S. Pistorale (2012): Stability analysis of forage production in Bromus catharticus (prairie grass) using three methodologies. Ciencia e investigación agraria 39: 331-338. 
Adugna, A., T. Tesfaye, E. Degu, T. Tadesse, F. Merga, W. Legesse, A. Tirfessa, H. Kidane, A. Wole and C. DABA (2011): Genotype-by-environment interaction and yield stability analysis in finger millet (Elucine coracana L. Gaertn) in Ethiopia. American Journal of Plant Sciences 2: 408-415.

Alia, R., G. Bozic, D. Gömöry, G. Huber, E. RAszTOVITS and G. VON WÜHLISCH (2010): The survival and performance of beech provenances over a Europe-wide gradient of climate, pp. 115-126. In: Monografias INIA: Serie Forestale No. 22. Genetic Resources of European Beech (Fagus sylvatica L.), edited by I. Aranda. Instituto Nacional de Investigación y Tecnología Agraria y Alimentaria, Madrid, ES.

Ammer, C., E. Bickel and C. Kolling (2008): Converting Norway spruce stands with beech a review of arguments and techniques. Austrian Journal of Forest Science 125: 3-26.

ArAndA, I., L. GIL and J. PARdos (1996): Seasonal water relations of three broadleaved species (Fagus sylvatica L., Quercus petraea (Mattuschka) Liebl. and Quercus pyrenaica Willd.) in a mixed stand in the centre of the Iberian Peninsula. Forest Ecology and Management 84: 219-229.

Athanasiou, K., B. C. Dyson, R. E. Webster and G. N. Johnson (2010): Dynamic Acclimation of Photosynthesis Increases Plant Fitness in Changing Environments. Plant Physiology 152: 366-373.

Babić, V., M. Babić, M. Ivanović, M. KRaluevićBALAlić and M. DimitriJEvić (2010): Understanding and utilization of genotype-by-environment interaction in maize breeding. Genetika 42: 79-90.

Baltunis, B. S., W. J. Gapare and H. X. Wu (2010): Genetic parameters and genotype by environment interaction in Radiata pine for growth and wood quality traits in Australia. Silvae Genetica 59: 113-124.

Bellard, C., C. Bertelsmeier, P. Leadley, W. Thuiller and F. Courchamp (2012): Impacts of climate change on the future of biodiversity. Ecology Letters 15: 365-377.

Blum, A., 2005: Drought resistance, water-use efficiency, and yield potential - are they compatible, dissonant, or mutually exclusive? Australian Journal of Agricultural Research 56: 1159-1168.

Bose L. K., N. N. JAMbhulkar, K. PANDE and O. N. SingH (2014a): Use of AMMI and other stability statistics in the simultaneous selection of rice genotypes for yield and stability under directseeded conditions. Chilean Journal of Agricultural Research 74: 3-9.

Bose, K. L., N. N. Jambhulkar and K. PAnde (2014b): Genotype by environment interaction and stability analysis for rice genotypes under Boro condition. Genetika 46: 521-528.

Bugmann, H. (1997): Sensitivity of forests in the European Alps to future climatic change. Climate Research 8: 35-44.
CRossa, J. (1990): Statistical analysis of multi location trials. Advances in Agronomy 44: 55-86.

Czajkowski, T. and A. Bolte (2005): Unterschiedliche Reaktion deutscher und polnischer Herkünfte der Buche (Fagus sylvatica L.) auf Trockenheit. [Different reaction of beech (Fagus sylvatica L.) provenances from Germany and Poland to drought]. AllgemeineForst- und JagdZeitung 177: 30-40.

Dounavi, A., F. Netzer, N. Celepirovic, M. IvanKović, J. Burger, A. G. FigueroA, S. Schön, J. Simon, E. Cremer, B. Fussi, M. Konnert and H. Rennenberg (2016): Genetic and physiological differences of European beech provenances (F. sylvatica L.) exposed to drought stress. Forest Ecology and Management 361: 226-236.

Eberhart, S. A. and W. A. Russell (1966): Stability Parameters for Comparing Varieties. Crop Science 6: $36-40$.

Eilmann, B., F. Sterck, L. Wegner, S. M. G. DE VRIES, G. von ARX, G. M. J. Mohren, J. DEN OUdEN and U. SASS-KLAASSEN (2014): Wood structural differences between northern and southern beech provenances growing at a moderate site. Tree Physiology 34: 882-893.

FALKENHAGEN, E. (1996): A comparison of the AMMI method with some classical statistical methods in provenance research: the case of the South African Pinus radiata trials. Forest Genetics 3: 81-87.

FARshadfar, E., M. Geravandi and Z. VAISI (2012): Chromosomal localization of QTLs controlling genotype $\times$ environment interactions in barley. International Journal of Agriculture and Crop Sciences 4: 317-324.

Finlay, K. W. and G. N. Wilkinson (1963): The analysis of adaptation in a plant-breeding programme. Australian Journal of Agricultural Research 14: 742-754.

GAUCH, H. G. (1988): Model selection and validation for yield trials with interaction. Biometrics 44: 705-715.

Gwaze, D. P., J. A. Wolliams, P. J. Kanowski and F. E. BRIDGWATER (2001): Interactions of genotype with site for height and stem straightness in Pinus taeda in Zimbabwe. Silvae Genetica 50: 135-140.

Hannerz, M., J. Sonesson and I. Ekberg (1999): Genetic correlations between growth and growth rhythm observed in a short-term test and performance in long-term field trials of Norway spruce. Canadian Journal of Forest Research 29: 768-778.

Hannrup, B., G. Jansson and Ö. Danell (2008): Genotype by environment interaction in Pinus sylvestris L. in Southern Sweden. Silvae Genetica 57: 306-311.

Hogberg, K. A. and B. KarLsson (1998): Nursery selection of Picea abies clones and effects in field trials. Scandinavian Journal of Forest Research 13: 12-20.

Ivanković, M., M. Popović, I. Katičıć, G. vON WUEHLISCH and S. BoGDAN (2011): Quantitative genetic variation of European beech (Fagus sylvat- 
ica L.) provenances from the southeastern Europe. Sumarski list: 25-37.

JazBec, A., K. Segotić, M. Ivanković, H. MaRjanović and S. PERIĆ (2007): Ranking of European beech provenances in Croatia using statistical analysis and analytical hierarchy process. Forestry 80: 151-162.

Jump, A. S., J. M. Hunt and J. Penuelas (2006): Rapid climate change-related growth decline at the southern range edge of Fagus sylvatica. Global Change Biology 12: 2163-2174.

Karimizadeh, R., M. Mohammadi, M. Armion, M. K. ShefazADEH and H. Chalajour (2012): Determining heritability, reliability and stability of grain yield and yield-related components in durum wheat (Triticum durum L.). Bulgarian Journal of Agricultural Science 18: 595-607.

KARLSSON, B. and K. HogBerg (1998): Genotypic parameters and clone $\times$ site interaction in clone tests of Norway spruce (Picea abies (L.) Karst.). Forest Genetics 5: 21-30.

Kim, I., H. Kwon, K. RYU and W. Y. CHOI (2008): Provenance by Site Interaction of Pinus densiflora in Korea. Silvae Genetica 57: 131-139.

KoskelA, J., A. BuCK, E. Teissier DU CROs (2007): Climate change and forest genetic diversity: Implications for sustainable forest management in Europe. Bioversity International, Rome.

Krstić, M., M. Medarević, Lj. Stojanović and S. BANKOVIĆ (2002): State and silvicultural problems of beech forests in Northeast Serbia. Bulletin of the Faculty of Forestry 86: 161-171.

LENORMAND, T. (2002): Gene flow and the limits to natural selection. Trends in Ecology and Evolution 17: 183-189.

LINDNER, M. (2007): How to adapt forest management in response to the challenges of climate change?, pp. 31-42. In: Climate change and forest genetic diversity: Implications for sustainable forest management in Europe, edited by J. KoskELA, A. Buckand E. Tessier Du Cros. Bioversity International, Rome, Italy.

Lindner, M., J. Garcia-Gonzalo, M. Kolström, T. Green, R. Reguera, M. MaroscheK, R. Seidl, M. J. Lexer, S. Netherer, A. Schopf, A. Kremer, S. Delzon, A. Barbati, M. Marchetti and P. CoRona (2008): Impacts of climate change on European forests and options for adaptation. Report to the European Commission Directorate-General for Agriculture and Rural Development. pp. 173.

Lindner, M., M. MaroscheK, S. Netherer, A. KreMer, A. Barbati, J. Garcia-Gonzalo, R. Seidl, S. Delzon, P. Corona, M. Kolstrom, M. Lexer and M. MARChetTi (2010): Climate change impacts, adaptive capacity, and vulnerability of European forest ecosystems. Forest Ecology and Management 259: 698-709.

LitTvay, T. (2011): Phenotypic stability and adaptability of families of common walnut (Juglans regia L.) in progeny tests. S̆umarski list 13: 38-45.
Matheson, A. C. and C. A. RAYMond (1986): A review of provenance $\mathrm{x}$ environment interaction: its practical importance and use with particular reference to the tropics. Commonwealth Forest Review 65: 283-302.

McKeand, S. E., B. Li, A.V. Hatcher and R. J. Wei (1990): Stability parameter estimates for stem volume for loblolly pine families growing in different regions in the southeastern United States. Forest Science 36: 10-17.

Mclachlan, J. S., J. J. HellmanN and M.W. SCHWARTZ (2007): A framework for debate of assisted migration in an era of climate change. Conservation Biology 21: 297-302.

Mirosavljevic, M., N. Przulu, J. Bocanski, D. Stanislavjevic and B. Mitrovic (2014): The application of AMMI model for barley cultivars evaluation in multi-year trials. Genetika 46: 445-454.

MoHAmmadi, R. and A. Amri (2011): Graphic analysis of trait relations and genotype evaluation in durum wheat. Journal of Crop Improvement 25: 680-696.

Muhs, H. J., L. Paule, L. Ionita and G. von Wuehlisch (2010): Concept and design of the international beech provenance trials of 1995 and 1998, and suggestions for future trials. Book of abstracts. COST E52 "Evaluation of Beech Genetic Resources for Sustainable Forestry" Final Meeting. 4-6 ${ }^{\text {th }}$ May 2010, Burgos, Spain. p. 19.

MuRILlo, O. (2001): Genotype by environment interaction and genetic gain on unbalanced Pinus oocarpa provenances trials. Agronomía Costarricense 25: 21-32.

Odewale, J. O., C. D. Ataga, C. Agho, G. Odiowaya, M. N. OKoye and E. C. Okolo (2013): Genotype evaluation of coconut (Cocos nucifera L.) and mega environment investigation based on additive main effects and multiplicative interaction (AMMI) analysis. Research Journal of Agricultural and Environmental Management 2: 1-10.

PERKINs, J. M. and J. L. JINKs (1968): Environmental and genotype-environmental components of variability. III. Multiple lines and crosses. Heredity 23: 339-356.

Ponton, S., J. Dupouey, N. Bréda and E. Dreyer (2002): Comparison of water-use efficiency of seedlings from two sympatric oak species: genotype $\times$ environment interactions. Tree Physiology 22: 413-422.

Pswarayi, I. Z., R. D. Barnes, J. S. Birks and P. J. Kanowski (1997): Genotype-Environment Interaction in a Population of Pinus elliottii EnGELM. var. elliottii. Silvae Genetica 46: 35-40.

Purchase, J. L., H. Hatting and C. S. Vandeventer (2000): Genotype $\times$ environment interaction of winter wheat (Triticum aestivum L.) in South Africa: II. Stability analysis of yield performance. South African Journal of Plant and Soil 17: 101-107. 
Ramburan, S., M. Zhouand M. LABuschagne (2011): Interpretation of genotype? environment interactions of sugarcane: Identifying significant environmental factors. Field Crops Research 124: 392-399.

RAYMOND, C. A. and G. NAmKoong (1990): Optimising breeding zones: Genetic flexibility or maximum value? Silvae Genetica 39: 110-112.

Rezene, Y., A. BeKele and Y. GoA (2014): GGE and AMMI biplot analysis for field PEA yield stability in SNNPR State, Ethiopia. International Journal of Sustainable Agricultural Research 1: 28-38.

Robson, T. M., D. SAŃchez-Gómez, F. J. CANo and I. ARANDA (2012): Variation in functional leaf traits among beech provenances during a Spanish summer reflects the differences in their origin. Tree Genetics and Genomes 8: 1111-1121.

RWEYONGEZA, D. (2011): Pattern of genotype-environment interaction in Picea glauca (Moench) Voss in Alberta, Canada. Annals of Forest Science 68: 245-253.

SAS Institute, InC. (2011): SAS/STAT Users Guide, Version 9.1.3. Cary, NC: SAS Institute, Inc.

ShAFII, B. and W. J. PRICE (1998): Analysis of genotype-by-environment interaction using the additive main effects and multiplicative interaction model and stability estimates. Journal of Agricultural, Biological, and Environmental Statistics 3: 335-345.

StatSoft, InC. (2013): STATISTICA (data analysis software system), version 12 .

Stojanović, D. B., A. Kržıć, B. Matovic, S. Orlovic, A. Duputie, V. DJurdjevic, Z. Galic and S. Stojnic (2013): Prediction of the European beech (Fagus sylvatica L.) xeric limit usinga regional climate model: An example from southeast Europe. Agricultural and Forest Meteorology 176: 94-103.

Stojnić, S., S. Orlović, Z. Galić, V. Vasić, D. Vilotić, M. KneŽEvić and M. ŠJjaC̆IĆ-NiKOLIĆ (2012): Environmental characteristics in the European beech provenance trials at Fruška Gora Mountain and Debeli Lug. Topola/Poplar 189/190: 145-162. [in Serbian with English summary]

Stojnić, S., U. SAss-KlaAssen, S. Orlovic, B. Matovic and B. Eilmann (2013a): Plastic growth response of European beech provenances to dry site conditions. IAWA Journal 34: 475-484.

STOJNIĆ, S. (2013b): Variability of anatomical, physiological and morphological traits of different European beech provenances in Serbia. $\mathrm{PhD}$ thesis, University of Belgrade Faculty of Forestry, Republic of Serbia. pp. 340. [in Serbian with English summary]
Sykes, R., B. LI, F. IsIK, J. KADlA and H-M. ChANG (2006): Genetic variation and genotype by environment interactions of juvenile wood chemical properties in Pinus taeda L.. Annals of Forest Science 63: 897-904.

Thiel, D., J. Kreyling, S. Backhaus, C. BeierkuhnLein, C. BuhK, K. Egen, G. Huber, M. Konnert, L. NAGY and A. JENTSCH (2014): Different reactions of central and marginal provenances of Fagus sylvatica to experimental drought. European Journal of Forest Research 133: 247-260.

VIS̆NJIĆ, Ć. (2010): Variability of some morphological characteristics of 16 provenance of the European beech (Fagus sylvatica L.). Works of the Faculty of Forestry University of Sarajevo 2: 55-70.

vON WueHLISCH, G. (2004): Series of International Provenance Trials of European Beech, pp. 135-144. In: Proceedings from the $7^{\text {th }}$ International Beech Symposium IUFRO Research Group 1.10.00 Improvement and Silviculture of Beech, edited by K. Sagheb-Talebi, P. Madsen and K. Terazava. Tehran, Iran.

VON WUEHLISCH, G. (2008): EUFORGEN Technical Guidelines for genetic conservation and use for European beech (Fagus sylvatica). Bioversity International, Rome, Italy.

VON WueHLISCH, G. (2010a): Introductory note, pp. 8-9. In: Genetic resources of beech in Europe current state, edited by J. FRÝDL, P. NovotnÝ, J. Fennessy and G. von WüHLISCH. Johann Heinrich von Thünen-Institut, Braunschweig, Germany.

von Wuehlisch, G., D. Ballian, S. Bogdan, M. Forstreuter, R. Giannini, B. Götz, M. Ivankovic, S. Orlovic, A. Pilipovic and M. SiJacic Nikolic (2010b): Early results from provenance trials with European beech established 2007. Book of abstracts. COST E52 "Evaluation of Beech Genetic Resources for Sustainable Forestry" Final Meeting. 4-6 ${ }^{\text {th }}$ May 2010, Burgos, Spain. p. 19.

Wortemann, R., S. Herbette, T. S. Barigah, B. Fumanal, R. Alia, A. Ducousso, D. Gomory, P. Roeckel-Drevet and H. Cochard (2011): Genotypic variability and phenotypic plasticity of cavitation resistance in Fagus sylvatica L. across Europe. Tree Physiology 31: 1175-1182.

Zas, R., E. Merlo and J. Fernández-López (2004): Genotype $\times$ environment interaction in Maritime pine families in Galicia, Northwest Spain. Silvae Genetica 53: 175-182.

Zobel, R.W., M. J. Wright and H. G. Gauch (1988): Statistical analysis of a yield trial. Agronomy Journal 80: 388-393. 